\title{
MAGYAR NYELVŰ MAGYAR ORVOSI NYELVET!
}

\section{LET HUNGARIAN MEDICAL LANGUAGE BE HUNGARIAN}

\author{
Bősze Péter \\ az MTA doktora, egyetemi tanár, Fővárosi Szent István Kórház Szülészeti és Nőgyógyászati Osztály \\ bosze@eagc.eu
}

\begin{abstract}
ÖSSZEFOGLALÁS
A magyar orvosi nyelv keveréknyelv: a nevezetek többsége görög-latin, újabban angol. A ránk maradt görög-latin középkori hagyomány; Habsburg gyarmati sorsunk nem tette lehetővé, hogy honi nyelvünkre cseréljük - miként tették ezt a fejlett nemzetállamok a XVI-XVIII. században. Még nagyobb baj, hogy a meglévő magyar szakkifejezéseket vagy a könnyen magyarosíthatókat sem használjuk, az idegenek bűvöletében élünk. A görög-latin nevezetek használatának semmi előnye nincs: nem illenek bele nyelvünkbe, de a nemzetközi orvosi nyelvbe sem. Hátrányuk viszont tetemes.

Ismert, hogy az anyanyelv határozza meg a társadalmak műveltségét, versenyképességét, az anyanyelv versenyképessége - képes-e megtartani az anyanyelvi közösséget - pedig az anyanyelvi szak-, de főleg a tudománynyelvek fejlettségétől függ. Ha az anyanyelvi tudományos nyelvek nem kellően fejlettek, az anyanyelv és a közösség sem lesz versenyképes. Ennek távlati következménye: beolvadás, nyelvcsere. Ezért elengedhetetlen a magyar nyelvű magyar orvosi (tudományos) nyelvünk megteremtése. A magyar nyelvű orvosi nyelvnek egyébként számos más előnye is van, kiemelve azt, hogy a magyar nevezetek meghatározása pontosan igazítható a nemzetközi megfelelők jelentéséhez, sőt árnyaltabb is lehet.

A magyar nyelvű orvosi nyelv (és más tudományok magyar nyelvű tudománynyelvének) létrehozása nem halasztható tovább, felelősségünk óriási. Nem szabad a magyar nyelvet a konyhanyelv szintjére süllyeszteni, hogy csak a hétköznapi kapcsolatokban használjuk, a tudományban nem. Ha a társadalom nem érti a tudományt, nem lesz müvelt. Korunk a szaknyelvek, tudománynyelvek újításának kora, és ha nem lépünk Kazinczyék, Bugáték nyomdokaiba, a magyar nyelvünk emberöltők távlatában elveszti versenyképességét, annak végzetes következményeivel.
\end{abstract}

\section{ABSTRACT}

The Hungarian medical language is a kind of mixture: most technical terms in it are of Greco-Roman or, more recently, English origin. The Greco-Roman part is a tradition going back to the Middle Ages; the fact that Hungary was part of the Habsburg Empire made it impossible to change it into Hungarian unlike in other countries in the 16-18th centuries. It is even more problematic that we do not tend to use even the existing Hungarian terms or ones that can be easily Hungarianized; rather, we rest content with international terms. The use of Greco-Roman terms has no advantage whatsoever: they do not fit into Hungarian, or into the international medical parlance, either. Their drawbacks, on the other hand, are numerous. 
As is widely known, it is the first language of a community that determines its level of education and its competitiveness, and the competitiveness of a language - whether or not it is able to keep the language community in existence - depends on the development of specialized terminologies in that language, especially those of the various sciences. If the scientific terminologies of a language are not sufficiently well-developed, that language and the community that speaks it will not be competitive, either. In the long run, the consequence is assimilation and language shift. That is why it is absolutely essential to help to create a Hungarian medical language that is truly Hungarian. Such a Hungarianized medical language would have a number of additional advantages, including the possibility of exactly matching up the meanings of newly created terms with their international equivalents or even making them more nuanced.

The creation of Hungarian medical language (as well as that of other sciences) is a task that cannot be postponed any further, we bear enormous responsibility fulfilling it. We must not let Hungarian become a 'restricted code' that can be used in everyday situations but not is writing science. If a language community cannot understand scientific writing, it will not be sufficiently educated. Our's is an age is of the revitalization of technical terminologies: if we do not follow the footsteps of Ferenc Kazinczy or Pál Bugát, two renowned Hungarian language reformers of the nineteenth century, Hungarian may lose its competitiveness in a few generations' time, with all the disastrous consequences that loom large.

Kulcsszavak: magyar nyelvű magyar orvosi nyelv, magyar nyelvű orvosi nevezetek

Keywords: Hungarian medical language using, Hungarian terminology and medical terms

Amit elmulasztottak a századok!

„Nem szabad ennyire magyarítani, mert a mai orvosok természetesen használják a kevert nyelvet; az ennyire steril magyar az olvasást nagyban nehezíti, mert nem erre áll rá az agyuk. Én nem erőltetném. A Tulassay onkológiai könyv volt enynyire magyarítva, a hallgatók azt mondják, kínszenvedéssel olvassák. Ne essünk ebbe a hibába.” A Nőgyógyászati Onkológia címü folyóirat egyik szerzője írta a szerkesztő által magyarított kéziratuk olvasásakor, és visszaállította az idegen nevezeteket.

\section{AZ ANYANYELVI TUDOMÁNYNYELV JELENTŐSÉGE}

„A társadalmi nyelvváltozatok [...] között a nyelvközösség társadalmi versenyképessége szempontjából a szaknyelvek kiemelten fontosak. Két fő csoportjuk van: a foglalkozási szaknyelvek (másként a mesterségnyelvek) és a tudományos nyelvek. Ezeknek, elsősorban azonban az utóbbiaknak a fejlettsége határozza meg ugyanis jelentős mértékben a nyelvek versenyképességét is (s nem pedig 
- például - a hobbinyelvek vagy a szleng). Versenyképes nyelv nélkül pedig nincs versenyképes társadalom sem.” - írta Kiss Jenő (Kiss-Pusztai, 2018, 350.).

A tudománynyelvek a mesterségnyelvektől abban különböznek, hogy szókincsük jóval bővebb és rendezett: nevezék- (nomenklatúra) és nevezettanban (terminológia) foglalt rendszerek - a nevezettan tehát a tudományos nyelvek sajátja. A nevezeteket (terminus technicusok) nemzetközi bizottságok határozzák meg, és csoportosítják fogalomkörök szerint. A tudományok szókészlete még a kezdetekkor a népnyelvből fejlődött ki, de csakhamar a tudatos szóalkotás került elötérbe. Korunkban a tudományos nyelvek nevezettára robbanásszerủen bővül, csak a müszóalkotás tarthat lépést vele. „A tudományos nyelveket az állandó nyelvújítás jellemzi." (Kiss-Pusztai, 2018, 355-356.).

Az európai tudományos nyelvek sorsa a 16. századig a kolostorokhoz volt kötve; az arab és görög orvosi irodalmat a szerzetesek fordították középkori göröglatinra. A 16. századtól viszont az egyetemek formálták, rendszerezték a tudományok nyelvét. Amelyik országban nem volt egyetem, a nemzeti tudománynyelvek is háttérben maradtak, legfeljebb a külföldön tanult tudósok (peregrinusok) terjesztették a tudományos ismereteket, többnyire görögül-latinul. Az egyetemeken a középkori görög-latin tudományos nyelvet anyanyelvre cserélték, tudva, hogy az anyanyelvnek közösséget formáló szerepe van, meghatározó a társadalom müvelödésében - végeredményben a tudatosuló közösségek igénye tette szükségessé. Az anyanyelvi tudományos nyelvek tehát nemcsak az anyanyelvi tudományok létezésének a letéteményesei, hanem a müvelt társadalom kialakításának is.

Az értelmiség nyelvi felelősségéről Kiss Jenő így írt: „Tény- és tárgyszerüen fogalmazva: minden nyelvnek csak akkor van jövöje, ha van elegendő biológiai utánpótlása (ha tehát születnek gyermekek kellő számban, akiknek a szülök, környezetük továbbadja az anyanyelvet), és ha vannak anyanyelvüket teljes funkciókörben megtartó és használó felnőttek. Versenyképes pedig addig lesz ez a nyelv, ameddig anyanyelvi értelmisége gondoskodik az anyanyelvi köznyelv és a szaknyelvek karbantartásáról, korszerüsítéséröl, az anyanyelvi közösség körében történő minél szélesebb körü elterjesztéséről - beleértve az anyanyelvü tudománymüvelést, a tudományos képzést és a tudományos ismeretterjesztést is." (Kiss, 2012)

A nyelvi és a közösségi jellemzők összetartozása nem új gondolat. Decsy Sámuel már a 18. században leírja, hogy a közösség sorsára a nyelv keresztmetszetén át vethetünk pillantást (Decsy, 1790).

Összegezve megállapítható, hogy az anyanyelv határozza meg a társadalmak müveltségét, versenyképességét, az anyanyelv versenyképessége - képes-e megtartani az anyanyelvi közösséget - pedig az anyanyelvi szak-, de föleg a tudománynyelvek fejlettségétől függ; mennyire alkalmasak a tudományok anyanyelvi müvelésére. Ha az anyanyelvi tudományos nyelvek nem kellően fejlettek, az anyanyelv és a közösség sem lesz versenyképes. Ennek távlati következménye: beolvadás, nyelvcsere. 


\section{MAGYAR ORVOSI NYELVÜNK ÉS HASZNÁLATA 2019-BEN}

Keverék az orvosi nyelvünk, a nevezetek többsége görög-latin (még a középkorból hagyományozódott), és egyre több az angol. Ha megnézzük orvosi tankönyveink tárgymutatóit, rögtön szembeötlik, hogy a görög-latin szakkifejezések messze meghaladják a magyarokat.

Megnéztem szótárakban és szakkönyvek tárgymutatóiban a psych-/pszichelőtaggal kezdődő nevezeteket, a következőket találtam:

psychaesthesia/pszichesztézia, psychagógia/pszichagógia, psychalgia, psyhasthenia, psychiater/pszichiáter, psychiatria/pszichiátria, psychoanalysis/pszichoanalizis, psychochirurgia/pszichochirurgia, psychogen/pszichogén, psychogenia/pszichogénia, psychohygiene/pszichohigiéné, psychopatha/pszichopata, psychometria/pszichometria, psychoneurosis/pszichoneurózis, psychopathia/ pszichopátia, psychopharmacologia/pszichofarmakológia, psychophisiologia/ pszichofiziológia, psychoprophylaxis/pszichoprofilaxis, psychosis/pszichózis ( alcoholica, $\sim$ arteriosclerotica, $\sim$ maniacodepressiva, $\sim$ polyneurotica alcoholica, $\sim$ puerperalis, $\sim$ senilis, affektív $\sim, \sim$ hallucinosis, indukált $\sim)$, psychosomatica/pszichoszomatika, psychotrauma/pszichotrauma psychosomaticus/ pszichoszomatikus, psychosyndroma/pszichoszindróma, psychotherapia/pszichoterápia, pszichoterapeuta, psychoticus/pszichotikus - a felsorolás nem teljes.

Magyar megfelelőjük, már amelyiknek van, elvétve fordult elő, de egy-egy magyar nyelvi szemléletü összeállítás azért akadt.

A példából is kitünik, hogy magyar nyelvü orvosi nevezettan jószerivel nincs, avagy rendkívül hiányos. Ám, ami még szomorúbb, a magyar nevezeteket általában nem is használják. Tudva, hogy az a szaknyelv, tudománynyelv, amelynek szókészlete zömében idegen, az anyanyelvi nevezeteinek használata pedig háttérben van, nem versenyképes, megállapítható, hogy a magyar nyelvü orvosi nyelvünk jelen szemléletében nem megfelelö! A keverék orvosi nyelvünkkel még boldogulunk, a magyar nyelvű orvosi nyelvünk azonban már korántsem használható. De - vélik egyesek - ezeket a görög-latin nevezeteket magyarosan írjuk, befogadtuk. Lehet, ám azért ezek mégsem magyar szavak: magyarosított idegenségek.

Természetesen vannak, akik orvosi nyelvünk használatáról más nézetet vallanak, akik szerint a megszokott, az egyetemen tanított és mindenki által értett görög-latin szakkifejezések használata teljesen helyénvaló, ezeket kell használni, nincs ezekkel semmi baj, évszázadok óta ez a szokás. Ök még nem vették észre, hogy álláspontjuk felett eljárt az idő.

Mások az angol szakkifejezések befogadását szorgalmazzák, mondván: nyelvtudományi tény, hogy a befogadott idegen szakkifejezések, a jövevényszók csak gazdagítják nyelvünket. Ez a nézet is téves: a csordultig telt pohárba nem lehet 
többet tölteni, mert kicsordul. A magyar szókészlettel is kifejezhető minden, mellőzhető az új idegen szó. Nagyon, nagyon kevés új jövevényszóra van szükségünk, ugyanakkor az angol szakkifejezések elárasztanak bennünket.

\section{AZ IDEGEN ORVOSI NEVEZETEK ALKALMAZÁSÁNAK ELŐNYEI ÉS HÁTRÁNYAI A MAGYAR ORVOSI NYELVBEN}

Elönynek mondják, hogy többségük pontosan meghatározott, ezek terjedtek el, minden orvos érti, hagyományosak, és évszázadok óta ezeket tanítjuk.

Két megjegyzés:

- Biztonsággal állíthatom, hogy az orvosi nyelvünkben használt görög-latin nevezetek nem csekély része nem pontosan meghatározott, közöttük jelentős az értelmezési átfedés, ezért használatuk sem egységes. Márpedig az a szakkifejezés, amelyik nincs egyértelmúen meghatározva, nem felel meg a tudományos elvárásoknak.

- Kétségeim vannak afelől is, hogy mindegyik nevezetet minden szakmabeli érti is; a szakmaközi használatról nem is beszélve.

A szót nem elég érteni, azt is tudni kell, hogy mit takar. Igazából a fogalmat kell megérteni, amelyet sokszor egy odadobott idegen kifejezéssel elhomályosítunk. Ez az idegen kifejezés lehet, hogy a köztudatba teljesen átment, a mindennapi beszélgetés eleme, amelyről csak akkor derül ki, hogy nem pontosan körülhatárolt, vagy nem is tudjuk, hogy ténylegesen mit jelent, amikor magyarul akarjuk mondani. Ilyenkor nézegetjük a szótárakat, és igyekszünk rájönni, hogy tulajdonképpen mit is mondtunk.

\section{Hátrányok}

1. táblázat. Az idegen szavak használatának hátrányai

- A szükségtelen idegen szavakkal kevert írás nehezebben érthetö, félreérthetö, és nehezebben is megjegyezhető.

- Fokozottan magukban hordozzák a szótévesztés veszélyét.

- Hibás lehet írásuk és kiejtésük a nyelvünkből hiányzó hangok, szokatlan hangtársításaik miatt.

- Szürkíthetik a magyar nyelv sokszínüségét.

- A szükségtelen idegen szavaktól hemzsegő írások - tévesen - a nyelvünk szegénységének, elmaradottságának képzetét kelthetik.

- Magyar szakszöveg keverve az idegen szavak sokaságával visszatetszö: elvész a tömör, zamatos magyar szövegezés, a magyar nyelv sajátossága, amely - miként Szathmári István fogalmazott - a magyar nyelv legféltettebb kincse.

- Gátolja a tudományos ismeretek társadalmi szintü, szakmák közötti és szakmaközi terjesztését. 
Az idegen szavak használatának általános hátrányai mellett (1. táblázat) a tudományos idegen nevezetek három hátrányát külön is ki kell emelni:

- Az orvosi tudományos munkákban, jelentésekben stb. előforduló íráshibák többsége a görög-latin nevezetek helytelen írásából adódik. A felemás írásmód (cyszta, emótionális) - noha súlyos helyesírási hiba - mindennapi jelenség. Felemás társítás előfordul szószerkezetekben is (diabétesz mellitus), továbbá gyakran keletkeznek hibák a magánhangzók kiejtésbeli megnyúlásából adódóan (neutropenia - é-vel ejtjük, de ezt nem jelöljük, mégsem ritka a neutropénia írásmód); valamint az előtagok használatakor: nemcsak írásukkal (prae-, pre-), hanem helyesírási értelmezésükből adódóan is.

Például az antibiotikum szót sokan tévesen két szóösszetételi tagúnak tekintik - ezért az utótaggal helytelenül társítják (antibiotikum-kezelés) -, noha csak egytagú (mivel sem az anti-, sem a -biotikum nem fordul elö önmagában), tehát antibiotikumkezelés a szabályos írásmód.

Elterjedt a görög-latin nevezetek utótagjainak, ritkábban toldalékainak kötőjeles társítása (gastro-duodenalis, diabetes mellitus-ban), jóllehet ilyet a magyar helyesírási szabályzat soha nem javasolt; mindegyiket egybeírjuk (gastroduodenalis, diabetes mellitusban). Stb.

- A legtöbb nehézség a görög-latin kifejezésekkel mégis a magyaros vagy idegenes írásmódjukból keletkezik. Az orvosi folyóiratok többsége egyedi szerkesztési elveket vall, például a betegségneveket idegenesen, de másokat magyarosan, avagy mindent idegenesen, vagy éppen fordítva: mindent magyarosan stb. ír. Van olyan nézet, hogy a tudományos munkákban idegenesen, a nagyközönségnek szánt írásokban viszont magyarosan kell ezeket írni. Ezt a nézetet sem osztja mindenki. Az igazi hiba azonban ott van, ha egyazon könyvben, folyóiratban, netán közleményben mindkét írásmód elöfordul - néha még egy bekezdésen belül is. A kérdés szabályozatlan, de nem is igen szabályozható.

- Orvosi nyelvünk angolosodását Kontra Miklós $(1981,109$.) elemezte részletesen. A ,direkt kölcsönzés” - miként írja -, vagyis az, hogy a nyelvünkbe került szó (jövevényszó) általában az átadó nyelvi jelentésével együtt kerül az átvevő nyelvbe, a nyelvünkbe jutott angol orvosi nevezetekre teljesen igaz. A magyarosan írt domén és az angol domain jelentése tökéletesen fedi egymást. Tárgyalja, hogy a nyelvmüvelöknek figyelniük kell arra, hogy a kölcsönszó nyelvi hangalakja könnyen megtanulható és használható legyen. Ez a nehézség sincs, ha a magyart használom.

Az angol nevezetek írásával külön gond a helyesírási, toldalékolási, szóöszszetételi hibákon kívül az, hogy hajlamosít angolos fogalmazásra, angol szerkezetekkel kevert mondatok írására. Ez elsősorban bonyolult, terjengős mondatszerkesztéshez vezet, de gyakran keletkeznek zagyva, sem nem angol, sem nem magyar, hanem valamilyen öszvér nyelvi mondatok, bekezdések (,,angomagy" mondatszerkesztés) (Bősze, 2011, 88.). A terjengősség korunk orvosi tudományírásának mételye, létrejöttében szerepe van az angol nyelv hatásának 
is: a szerzők az egyszerű fogalmazás helyett az angol szerkezetek fordításával nyújtják a mondataikat. Sajátos helyesírási hiba a magyarosan írt angol szóöszszetételek különírása, mondván: az angol is különírja.

Összegezve, nehezen lehetne érvet találni az idegen nevezetek használatára. Hátrányuk viszont tetemes. Alkalmazásuk mégis általános: „így szoktuk meg”, „,́gy értik". Ezért írta a bevezetőben idézett szerző: Ne essünk abba a hibába, hogy a magyar nevezeteket kinszenvedéssel olvassák!

\section{RÉGI HAGYOMÁNY AZ IDEGEN ORVOSI NEVEZETEK HASZNÁLATA}

A hagyományőrzés több ezer éves kultúránk megmentésének alapja; a hagyományok tiszteletét, ápolását a génjeimben hordom. Így voltam orvosi nyelvünk görög-latin alapjainak, görög-latin alapú orvosképzésünk hagyományával is, amíg rá nem jöttem visszás voltára: a görög-latin alapú orvostudományunk ugyanis nem magyar kultúra, hanem közel félezer éves Habsburg gyarmati mivoltunk hátrányos maradéka:

A tudományokat a 16-17. században az erős nemzetállamok a latin mellett egyre inkább a nemzeti nyelveken is müvelték, megalkották az anyanyelvi szakkifejezéseket. Elengedhetetlen következménye volt ez annak, hogy müvelödött a társadalom, mivel megteremtődött a közmüvelés feltétele, a könyvnyomtatás: anyanyelven lehetett irodalmat, tudományt olvasni, vagy akár a múvészetekről is. A tudománynyelveket anyanyelvüvé az egyetemek alakították. Egyetemek ezekben az államokban már müködtek.

Hazánkban a nemzetállamosodás nem következett be: a Magyarország nagy részére kiterjedő török hódoltsági területen a létezésért kellett küzdenünk, a harcokban megfogytunk. A királyi országrészen németesítés folyt. Később a gyarmattá tett Magyarországon a Habsburgok gátolták, tiltották a magyar müvelődést: a közmüvelődés és a magyar szaknyelvek lemaradtak, noha szórványos erőfeszítéseket tudománynyelvünk fejlesztésére tettek néhányan, mint Szenczi Molnár Albert, Apáczai Csere János, Pápai Páriz Ferenc stb. Kiesett az a kétszáz év, a 16-17. század tudományfejlődése, amely alatt a nemzetállamok a középkori görög-latint nemzeti nyelvükre cserélték. A magyar orvosi szaknyelvben ezért maradt meg a görög-latin szókészlet, méghozzá olyan mélyen rögzülve, hogy orvosi nyelvünk kétnyelvüségéről is beszélhetünk.

A 19. század végén ugyan erőteljes magyarítási mozgalom bontakozott ki az orvosi nyelvben is, de a német nyelvü közéleti szereplés bővülésével háttérbe szorult. Ami elmaradt a 16-18. században, a középkori görög-latin orvosi szakszókészlet magyarra cserélése, a 19-20. században már nem valósulhatott meg - a császárság ezt sem engedte. 
Végeredményben megállapítható, hogy orvosi nyelvünk tetemes idegen szókészlete, beleértve a görög-latin nevezeteket, szakszavakat is, több évszázados tudományos elfojtottságunk maradványa. A szükségtelen idegen szavak a megszállásunkkal, elnyomásunkkal vonultak nyelvünkbe. Úgy is mondhatjuk, hogy a szükségtelen idegen szavak a nyelvünkben a magyar szellem történelmi hódoltságának, az ország elnyomatásának nyelvi lenyomatai (Bősze, 2018, 37.).

\section{IRÁNYZATOK AZ IDEGEN ORVOSI NEVEZETEK ALKALMAZÁSÁBAN}

Háromféle változás figyelhető meg. Az angol tudományírás túlsúlya az angol nevezetek terjedésével jár; ez orvosi nyelvünkben is jól megfigyelhető: megszámlálhatatlanul sok szükségtelen angol kifejezést alkalmaznak (off-label, uptake, high risk, low grade). Néhányat közülük már magyarosan is írnak, elindítva ezeket a jövevényszóvá válásuk felé (expresszál, amplifikált, pészméker, domén); sőt megjelent az angol és görög-latin társítás is (upregulálja). Ez újabb támadás a magyar orvosi nyelvünk ellen. A veszély nem csekély: sok-sok nevezetről van szó. Ha nem állítjuk meg terjedésüket, nem magyarítjuk az angol nevezeteket, a magyar nyelvü orvosi nyelvünk még sorvadtabb lesz.

Az angol szakkifejezések terjedése újabb felemássághoz vezetett: egyazon magyar tudományos közleményben görög-latin és angol nevezetek is keverednek.

Terjed a görög-latin szakkifejezések angolosodása. Orvosi nyelvünkben, de a köznyelvben is, szép számban vannak az olyan görög-latin eredetủ szavak, amelyeknek az angolos formáját használjuk. Például az oralis helyett oral, a thyreoid utótagú szavakból elmarad az $e$ betü (hyperthyroidosis a hyperthyreoidosis helyett), avagy mimikál a mímel helyett, pszichotikus a pszichés, szisztolikus a szisztolés helyett, szekretál a szecernál helyett stb.

Átalakulóban van a magyar nevezetek változataként megadott idegen kifejezések írása: egyre inkább a nemzetközi angolt adjuk meg, még a szokásos görög-latin helyett is. Észszerủ változás: pontosabb a nemzeti és a nemzetközi nevezetek összevetése.

Összegezve: hagyományos görög-latin orvosi nyelvünk angolosodik; a holt nyelv angol köntöst véve támad fel.

\section{A MAGYAR NEVEZETEK ALKALMAZÁSÁNAK ELŐNYEI, HÁTRÁNYAI}

Több sarkalatos előny fogalmazható meg (Bősze, 2019, 27.). A legjelentősebb, hogy a magyar nevezetek alkalmazása a magyar nyelvü orvosi nyelv létezésének az alapja. Magyar orvosi nevezetek nélkül nincs versenyképes magyar orvosi nyelv és magyar orvostudomány sem. A magyar nyelvü tudománynyelvek nélkül 
pedig a magyar nyelv sem versenyképes. A nyelvek versenyképessége ugyanis a szaknyelvek, tudománynyelvek fejlettségén áll vagy bukik.

További előnyök: Kiküszöböli az idegen nevezetek alkalmazásával járó hátrányokat (helyesírási, kiejtési, tévesztési, mondatszerkesztési hibák stb.). Lehetővé teszi egyrészt, hogy a nem szakemberek is megértsék az orvosi tájékoztatást (betegtájékoztatás, orvosi leletek, zárójelentések), másrészt elősegíti a közmüvelést és az egészségre nevelést az orvosi ismeretek, valamint a betegségmegelőzés lehetőségének terjesztésével. Valamint, hogy a magyar nevezetek meghatározása pontosan igazítható a nemzetközi megfelelök jelentéséhez, sőt árnyaltabb is lehet (2. táblázat).

2. táblázat. Részlet a készülő magyar orvosi értelmező szótárból

jelzés* signal irányító jel. Az élő szervezet szabályozása a kölcsönhatások eredménye, a kölcsönhatások pedig jelzésekkel valósulnak meg, azaz jelzéses szabályozással. A sejteket a jelzések „végtelen” rendszere hálózza be, müködteti és hangolja össze tevékenységüket. jelzésadás* signaling valamely sejt által kiadott jelzés; lehet közvetlen vagy közvetett $(\rightarrow$ jelzéskapcsolat).

jelzéskapcsolat* jelzésekkel megvalósuló kapcsolat. A biológiában a sejtek közötti és a sejten belül, a sejtszervecskék közötti kapcsolat. Lehet közvetlen (a jelzéskapcsolatban részt vevők érintkeznek egymással) és közvetett (köztes molekulákkal megvalósuló). jelzéspálya* signaling pathway a jelzés keletkezésétől a jelzés végrehajtásáig terjedő folyamatok összessége. Külső vagy belső kémiai, fizikai inger indítja el. Az ingert érzékelő sejt kibocsátja a jelzést szállító molekulát, ezt a célsejt fogadja, átszállítja a sejtplazmán a végrehajtó molekulához.

jelátadó* ligand a közvetlen jelzéskapcsolatban a jelzést a jelfogónak továbbító molekula, pl. sejtfelszíni molekula, amely kötődik a másik sejt jelfogójával. Végeredményben szállítást nem végző jelvivő.

jelátvitel* signal transduction a jel fogadása, megfejtése és átvitele a sejtfalon. A sejtfali jelfogó hajtja végre.

jelfogó receptor a jelzést szállító molekulát fogadó sejtfehérje.

jelközvetítés* signal pathway a jelzés továbbadásának sejten belüli szakasza. Az idegsejtek akciós potenciáljától eltekintve, molekulák végzik; jelfogótól a végrehajtó molekuláig/DNS-ig tart.

jelszakasz* a jelközvetítés része.

jelvitel* a jelvivő keletkezése, a jelzés elvitele és átadása a jelfogónak.

jelvivő ligand a jelzést a jelfogóhoz szállító molekula.

jelvonal* a jelpályának a jelfogótól a végrehajtásig terjedő része.

jelzésberekesztés* a jelzésadás/sejtválasz megállítása.

jelzésvégrehajtás* a jelzésre bekövetkező sejtválasz: a DNS-hez, ritkán RNS-hez jutott jelzés hatására bekövetkező fehérjeképződés. A jelzést a DNS-hez rendszerint a végrehajtó molekula juttatja el, amely kevés kivétellel átírásfehérje (transcription factor), de előfordul, hogy a jelközvetítés utolsó molekulája kapcsolódik a DNS-hez.

*A csillaggal jelölt nevezetek a szerző javaslatai. Vannak olyanok is, amelyeknek nincs pontosított angol változata. 
A példa jól mutatja, hogy a magyar nevezetekkel a nemzetközinél is részletesebben kifejezhető a jelzés folyamatának mindegyik része. Az olvasó rögtön tudja, hogy melyik részéről van szó, például: a jelközvetités valamelyik enzime... leírásból egyértelmü, hogy a sejten belüli jeltovábbítás egyik enziméröl beszélünk. Nem gondolnám, hogy ezeket az elnevezéseket nehezebb megtanulni, mint azt, hogy signaling, signal transduction, pathway, ligand stb.

Hátrányok. A magyar nyelvű orvosi nyelv használatának valós hátrányai nincsenek, átmeneti nehézségekkel azonban számolni kell. Miként a bevezető idézet utal rá, az orvostanhallgatók nehezen boldogulnak a magyar nevezetekkel, de csak azért, mert nem ezeket tanítjuk nekik, nem ezekkel találkoznak tankönyvekben, nem ezeket hallják. Tapasztalatból állítom, hogy használatukhoz rendkívül könnyü hozzászokni; én már a szükségtelen idegen kifejezések értelmezésével bajlódom.

\section{ÖSSZEGZÉS}

A magyar nevezetek megteremtésével, alkalmazásával szembeni folyamatosan hangoztatott ellenérv: a legfontosabb a megértés, a magyarítás nem mehet a megértés rovására, ezért túlzásokba nem szabad esni. Sőt még a megbélyegző „,purizmus" szó is elhangzik. Természetesen a félreérthetetlen fogalmazás kulcsfontosságú; az új, szokatlan magyar nevezet után zárójelben írt pontosító nemzetközi kifejezéssel ez teljesen megvalósítható. Ám nem erről van szó.

Senki ne áltassa magát azzal, hogy a hagyományos orvosi görög-latin nevezettan (terminológia, terminus technicusok, ha úgy tetszik) az idők távlatában megmenthetö; a nemzetközi felváltja. Ez a folyamat már feltartóztathatatlanul elkezdődött. A magyar nyelvü orvosi nyelvünk pedig csöbörből vödörbe esik, ha nem teremtjük meg, és nem alkalmazzuk a magyar nevezeteket. Tehát nem az a kérdés, hogy tartsuk-e meg vagy nem a hagyományos görög-latin szakkifejezéseket, hanem az, hogy magyar nevezetek legyenek helyettük, nem pedig angolok. Ha a magyar nevezetek terjesztése folyamatos, az egyetemen már azokat oktatjuk, a jövő nemzedékei számára már természetesek lesznek, miként már mindannyian természetesen használjuk például az osztály, mütő, nővér stb. Bugát-szavakat, amelyek a keletkezésük idején sokak ellenkezését váltották ki.

Meggyőződésem, hogy azok az orvosi tankönyvek, szakkönyvek, amelyek a görög-latin nevezettanra épülnek, már a mai negyvenes korosztály munkás éveiben nemcsak elavulnak, hanem a régmúlt részeivé válnak. Az ilyen könyvek címei után - miként a nyelvészek a régimódi szavak után - odatehetjük zárójelben, hogy (régi).

A huszonnegyedik órában vagyunk, a felelősségünk óriási. Nem szabad a magyar nyelvet a konyhanyelv szintjére süllyeszteni: ez történik, ha csak a hétköznapi kapcsolatokban használjuk, a tudományban nem. Ha a társadalom nem érti 
a tudományos nyelvet, félmüvelt lesz. Korunk a szaknyelvek, tudománynyelvek újitásának kora, és ha nem lépünk Kazinczyék, Bugáték nyomdokaiba, a magyar nyelvünk emberöltök távlatában elveszti versenyképességét, annak végzetes következményeivel.

Fordulóponton vagyunk, miként voltak eleink a 18. század végén, a nyelvújitás kezdetén. Akkor a német akart a magyar helyébe költözni, most az angol rakja fészkeit. Rajtunk múlik, hogy a fészkekböl ne angol, hanem magyar nevezetek keljenek ki.

\section{KÖSZÖNETNYILVÁNÍTÁS}

Hálás köszönetemet fejezem ki Kiss Jenő akadémikus úrnak a kézirat átnézéséért, javaslataiért és buzdításáért. Hasonlóan hálás vagyok Siptár Péter egyetemi tanár úrnak segítségéért, véleményezéséért.

\section{IRODALOM}

Bősze P. (2011): Angomagyos zagyvaságok. Magyar Orvosi Nyelv, 11, 2, 88-90. http://www.orvosinyelv.hu/dlObject.php?msz_id=21\&/MONY_2011_02.pdf

Bősze P. (2018): A magyar orvosi nyelv szükségtelen idegen szavainak kérdésköréhez. Magyar Orvosi Nyelv, 18, 1, 37-49. http://www.orvosinyelv.hu/dlObject.php?publikacio_id=375\&/ MONY_2018_01_A\%20magy_B\%C5\%91sze\%20.pdf

Bősze P. (2019): Magyar orvosi nyelv - nyelvhasználati megfontolások. Budapest, Medicina Kiadó

Decsy S. (1790): Pannóniai Féniksz, avagy hamvából fel-támadott magyar nyelv. Béts, https:// mandadb.hu/common/file-servlet/document/104752/default/doc_url/Pannoniai_Feniksz_ avagy_hamvabol_feltamadott_magyar_nyelv.pdf

Decsy S. (1790, 2005): Pannóniai Féniksz, avagy hamvából fel-támadott magyar nyelv-Pannonian Phoenix, or the Hungarian Language Arisen from the Ashes. (szerk. Gazda I. - Stemler Á.) (Első nyomtatott tudományos könyveink [16-19. század]. (Magyar-angol). Budapest: Országos Széchényi Könyvtár-Magyar Tudományos Akadémia

Kiss J. (2012): A magyar nyelv és nyelvközösség. (Szent György Könyvek) Budapest: Akadémia Kiadó

Kiss J. - Pusztai F. (szerk.) (2018): A magyar nyelvtörténet kézikönyve. (A magyar nyelv kézikönyvei) Budapest: Tinta Kiadó

Kontra M. (1981): A nyelvek közötti érintkezés néhány kérdéséröl, különös tekintettel „, elangolosodó" orvosi nyelvünkre. (Nyelvtudományi Értekezések, 109) Budapest: Akadémiai Kiadó 